\title{
The Impact of Tax Administration on Revenue Generation in Gombe State, Nigeria
}

\author{
Emmanuel Stephen $\mathbf{N}$ \\ Department of Accounting, Federal University Kashere, \\ P.M.B 0182, Gombe State, Nigeria.
}

\begin{abstract}
Taxes have been the bedrock of revenue generation to any government. The administration of tax is very important to any government as it is the body responsible for implementing and governing the tax laws and other tax related to assessment, collection and remittance of tax. This study is aimed at ascertaining the effect of tax administration on revenue generation in Gombe state. The study uses survey research design. The primary source of data collection was adopted, which analysed using descriptive statistics was made up of frequencies and simple percentages. Cronbach's Alpha diagnose was carried out to seek for reliability of the questions contained in the questionnaire Three Hypotheses were presented in this research and were tested using Spearman's Rank correlation, Pearson correlation and linear regression. Research findings indicated that Tax Administration in the state is not efficient and effective. The study revealed further that revenue generated in the state is low to meet its objectives due to low level of enlightenment of tax payers and incidents of tax evasion and tax avoidance. To this end, the study recommends, among others, that authorities should embark on more enlightenment campaign of citizens on the significance of paying Personal Income Tax, the quality and efficiency of tax workers should be improved so that more effective administration will be achieved and automation of the system.
\end{abstract}

Keywords: Tax Administration, Revenue Generation, efficiency and effectiveness, tax payers' enlightenment, tax evasion and avoidance, Gombe State, assessment, collection, remittance, Social Contract Theory

\section{Introduction}

The challenge of tax revenue generation and effective management of its administration is of great importance and vital to every government. Steps are always taken and regulations made for effective and efficient system of tax and its administration (Enahoro \& Olabisi, 2012).

Gurama and Mansor (2015) opines that the significance of tax to the development of a modern economy cannot be underline in any free society or a nation. Imposing and collecting taxes has been practice still in Gombe state long before the advent of colonial administrators, the tax is been Collected by the then local chiefs and emirs for the resolution of mainly defence and administration activities of their protectorates. Citizens are expected to comply by surrendering part of their earnings from rearing animals,' cultivation of farm land and other trade activities to the state, for the detriment of the public as a whole (Gurama\&Mansor, 2015).

Tax administration as a system in relation to assessment, collection and remittance is a strong vehicle which revenue is raised in the state to accomplish economic goals. Economic goals of the state can only be achieved when the tax system and manner of its administration is excellent. Taxes are levied in almost every country of the world, primarily to raise revenue for government expenditure although they serve other purpose as well. In modern economies, taxes are the most important sources of Government revenue and they represent a general obligation of tax payers are not levied or paid in exchange for any particular benefit (Enahoro \& Olabisi, 2012). 
Tax administrators have authority to urge taxpayers to pay their taxes. Consequently, tax administrators face various pressures from their stakeholders, particularly from the taxpayers, who demand excellent services. According to Darono (2015), the tax administration service is unique, because it must provide excellent services which make the taxpayer feel comfortable, but must also take coercive action (i.e., law enforcement).

Tax administration services include registering as a taxpayer, paying tax bills, reporting tax returns, filing objections against the tax billed, and claiming refunds for tax overpayments. Thus, the main function of the tax administration system is to reduce or eliminate asymmetric information between the taxpayers and tax officials (Darono, 2015).

Tax administration systems are complex, particularly in developing countries such as Nigeria (Darono 2015). The main problem is the flow of information, both from the taxpayer's side (i.e., the notification and supporting data) and from the tax officials' side (i.e., counter-transaction data from related parties). The phrase 'tax administration is tax policy' (Darono 2015) emphasizes why administrative matters receive a lot of attention from tax authorities in developing countries.

Abiola and Asiweh (2012) reveals that those working in the informal sector of the economy do not see the need to pay tax whereas they dominate the economy. To them only, civil servants should pay tax on their earnings and this amount to over flogging the willing horse. Besides, the activities of the strong union in the formal sector do not even pave way for a successful tax policy implementation in the formal sector (Abiola and Asiweh 2012). Even revenue collection officers seem to be lenient or even connive with those in the informal sector during enforcement of tax policies. All this leads to revenue loss. In other to reawaken the consciousness of Nigerian government and citizens on the effective use of taxation as a developmental tool, and examine the effect the tax system have so far on the economy; this research work becomes very relevant (Abiola and Asiweh 2012).

Enahoro (2012) opines that tax administration should be effective in the sense of ensuring high compliance by taxpayers, and efficient in the sense that administrative costs are low relative to revenue collected. Good tax administration requires strong technical capacity by the administrative agency but also a well-designed tax. The administrative agency should be able to identify and evaluate the effects of both current tax policies and tax policies under consideration, be able to simplify the current tax system if needed, within the economic and political spectrum, be aware of any law changes and emerging avoidance practices, and maintain a connection between the rule of law and tax administration (Enahoro 2012).Gombe state government has for a period of time been incapable of accomplishing its goals due to declining allocation from the federation account and also the low proceeds it is generating from its internal activities as a result of inadequate and inefficiency of prevailing tax collection (Gurama, 2015).

The procedures are orthodox in nature, in which staff of the board of internal revenue are used as sole tax collectors and remitted to the government. The problems related to the procedures are primarily associated with inadequate skills and inefficiency with enormous bribery and corruption among the tax officials. Lack of proper enlightenment on citizens on the importance and benefit of tax payment, and also the problem that lies with the machinery and approach adopted in collection, assessment and corrupt practices of tax officials in the tax system ((Gurama\&Mansor, (2015),Afuberoh\& Okoye, (2014), Hassan (2012)).

Therefore, in respect of the identified problems, this study will try to see how tax administration could affect the overall effectiveness of Gombe state revenue generation as regards tax administration. Also, the study will evaluate the problems that negatively affect tax administration and proffer solutions / feasible ways to this problems facing tax administration so as to help the state obtain sufficient revenue to accomplish its economic goals.

\subsection{Objectives of the Study}

The general objective of this study is to ascertain the effect of tax administration on revenue generation in Gombe state. The specific objective of the research is:

i. To examine the effect of efficiency and effectiveness of tax administration on revenue generation of Gombe State.

ii. To ascertain the relationship between tax payers' enlightening on tax payment and revenue generation in Gombe state.

iii. To determine the effect of tax evasion and avoidance on Revenue Generation. 


\subsection{Research Hypotheses}

In line with the objectives of the research, the hypotheses of the study have been formulated in null form:

$\mathrm{H}_{\mathrm{ol}}$ : Efficiency and effectiveness of tax administration has no significance effect on revenue generation of the state.

$\mathrm{H}_{\mathrm{o} 2}$ : There is no significant relationship between tax payers' enlightenment on payment of tax and revenue generation.

$\mathrm{H}_{\mathrm{o} 3}$ : Tax evasion and tax avoidance have no significant effect on revenue generation.

\subsection{Literature Review}

Limited studies have been conducted on tax administration in respect to revenue generation of different states and countries. Most of the researches established a positive effect and relationship between tax administration and revenue generation of the economy. For instance, Abiola and James, (2012) in Nigeria on tax administration and revenue generation; Enahoro and Olabisi, (2012) in Lagos state on tax administration and revenue generation; Angahar and Alfred, (2012) in Adamawa on personal income tax generation and tax; Kwame, Tchao and Poku (2013) in Ghana on Integration of Tax administration to grow economy and curb importation and tax evasion; Okoye and Ezejiofor, (2014) in Enugu on tax administration; Isaac, (2015) in Kaduna on contributions of tax revenue to economic development; Gbengi\& Adebisi (2013) in Abuja on Tax Avoidance and Tax Evasion on Personal Income Tax Administration; Ahuru and Oriakhi (2014) in Nigeria on tax reform and federal revenue generation; Okafor, (2012), in Nigeria on Revenue generation and economic development; Ifere\&Eko, (2014), in Cross River on tax administration, innovation and revenue generation; Efunboade,(2014) in Nigeria on Impact of ICT on Tax Administration in Nigeria; Abata, (2014) in Nigeria on Revenue and Economic growth; Chatama, (2013) in Tanzania on impact of ICT on taxation; and Hassan, (2012) in Kano state on tax administration and revenue generation.

However, studies by Nawaz (2010) in South Africa on Revenue generation and Corruption; Chandia et al (2014) in Pakistan on Revenue generation and Inflation; Madugba (2015) in Nigeria on Revenue generation and corporate tax; Wausi (2015) in Nigeria on Revenue generation and transfer pricing, all showed a negative relationship to revenue generation. Similarly, Mehrara (2016) in Iran on tax revenue and tax evasion established a $\mathrm{U}$ shape relationship.

Studies by Okoye (2014), Afuberoh (2014), Efunboade (2014), Samuel (2014), Adesoji (2013) and Chatama (2013), adopted only an aspect of tax administration which is tax collection and measured the extent of the relationship and significance it has towards a state's revenue generation. All their studies were also centered at the Federal Capital Territory (Abuja) and states in the Southern parts of Nigeria.

Gbengi (2013) and Angahar (2012) focused only on the effect of tax administration on personal income tax generation not on all tax collectable by the government.

Enahoro (2012) in his study used Kendall to analyze data collected in order to measure the relationship that exist between tax administration and revenue generation of an economy. Ifere (2014) in his case adopted simple percentage alone to measure the relationship and impact of tax administration, innovation and revenue generation. These methods does not really measure relationship and show significant in a regressive way as it would have if proper statistical regressive measures were adopted. However, Efunboade (2014) and Hassan (2012) used descriptive analysis to show the effect that tax administration have on revenue generation. To provide solution to the above problem therefore, this study used data from field study.

This research uses tax administration as an independent variable and revenue generation as dependent variable and the use and regression which measures effectively the relationship between variables and how they are related which is an improvement on Enahoro, (2012) study which was on Tax Administration and Revenue Generation of Lagos State which did not measure effectively this relationship. This is timely as the state's economy is facing low revenue generation and also low funding from the federation account due to dwindling proceeds from oil sales, there is therefore need to study how these problem could be solved.

In spite of the importance of tax to the development of any economy since tax is a principal source of government revenue, researches on revenue generation has mostly been geared towards its generation alone without much consideration to the administration (assessment, collection and remittance) which causes its generation. To maximize the collection of the needed tax revenue for the government, it is very important that the revenue agencies are efficient and effective in their duties as they aimed at satisfying the taxpaying 
public. Thus, there is need to examine the effect of tax administration on revenue generation. This study is carried out to fill this gap for the state and nation's revenue growth.

\subsection{Theoretical Framework: Social Contract Theory}

Social contract theory is a political theory. It is a theory that stresses an understanding between the ruled and their rules, characterizing the right and obligations of everyone accordingly (Hassan, 2012). According to Britannica, (1995- 920) new reference book state that in primitive times as indicated by the theory, individuals were naturally introduced to an anarchic state of nature, which was content or troubled as per the specific version, they then by practicing common reason framed society (Government) by means a contract between themselves. Notwithstanding comparative thoughts can be traced back to the Greek critic social contract scholar had their most notable century in the seventeenth and eighteenth hundreds of years and are connected with so many names as (Thomas Hobbes, 1851. john Locke, 1960. Jean-Jacques Rousseau, 1762).

This is relevant to taxation in which the citizens are eager to pay their taxes just when the government guarantees them of sufficient procurement of social amenities. For example, provision of power/electricity, good roads/streets networking, schools, job opportunities, hospitals/medical facilities, security and so forth. As a rule the taxpayers are frustrated when government neglects to give these civilities regardless of tremendous tax loads that they bear. Therefore, social contact theory help the profit standards of taxation which expresses that each taxpayer ought to hold up under tax burden in connection to the benefit which he or she get from open administrations or public services.

The Social Contract Theory which postulates that, there should be an understanding between the ruled and their rules, characterizing the right and obligations of everyone accordingly. When the tax administrators understands their role towards citizens and the citizens, that is the ruled also understand their duties and obligations and everyone does his part, then revenue would grow and if otherwise, revenue generation would be affected.

\section{RESEARCH METHODOLOGY}

Survey research design is adopted through the use of questionnaire, oral interview and personal observation. The research design is justified base on the nature of the data the researcher intends to collect and carry out analysis on.

The area of the study is the Gombe state government and the state board of internal revenue service in the state.

The population of workers in the state board of internal revenue is 125 . Due to the nature of the research in which experience and educational qualification was needed. The questionnaire would be administered on face to face to the employees of Gombe State Board of Internal Revenue, Gombe State, Nigeria and received on spot. The population for this study comprises of one hundred and twenty five (125) employees of State Board of Internal Revenue.

The sample size of ninety-five (95) was derived the sample size statistically by using Yaro Yamane (Adebisi, 2013).

Primary was used which was from the State Board of Internal Revenue Service of Gombe State with the aid of some prepared questionnaires which are differently answered by them. In addition, oral interview was conducted with some accounting officers of the Gombe State Board of Internal Revenue and Federal Inland Revenue. The options 'Yes/No' response types of question were structured. Others were unstructured to allow the respondents to provide their own answers.

Descriptive statistics was used in this study to compute the summary statistics that describe the central tendency, as well as, how the data spread out around this value. This tool is used to describe the dependent and independent variables of the study by computing the frequencies and percentages. Descriptive statistics is used to find out whether there is presence of an outlier or not in the variables.

Correlation Analysis is used to explain the strength and direction of a linear relationship between two variables (Pallant, 2011). Spearman's Rank correlation and Pearson correlation was employed to assess the interrelations among study variables. It showed the strength of the relationship between the independent variables among themselves and the dependent variable.

In order to determine the variation in dependent variable (revenue generation) due to variation in the independent variables (tax administration), linear regression technique is employed. This is because linear 
regression is expected to explain the variation in dependent variable due to the variation in the independent variables.

Diagnostic checks carried out on the model include Alpha test (to check whether there is a correlation and reliability among the explanatory variables).

There are three sets of variables covered by this study. These are the dependent and independent and the moderating variables. The dependent variable for this study is revenue generation of the state. This is measured by analyzing the responses on the rate of tax growth, the rate of increasing base and its buoyancy. The independent variable used in this study is Tax Administration (measured by its effectiveness and efficiency, autonomy, personnel, knowledge on tax system, able to make effective policies and law. The control variables included in the model are tax payers' enlightenment and tax evasion and avoidance.

The questionnaires will also be tested using the Alpha model and the at least $60 \%$ reliability would be adopted based on the findings and research by Sekaran (2010). The data were tested over and over again and same results are obtained, it means the information is very reliable.

\subsection{Test of Hypothesis}

The two types of hypotheses that are central in this study are the null and alternative hypotheses. The null hypotheses are stated in negative form being symbolized by $\mathrm{H}_{0}$ and its alternate $\mathrm{H}_{1}$. The statistical tests of the null hypothesis may suggest the rejection of the $\mathrm{H}_{0}$ at a particular level of significance and degree of freedom. The rejection of null hypothesis signals an automatic acceptance or non-rejection of the alternate hypothesis.

\subsection{Test of Hypothesis 1: $\mathrm{H}_{\mathrm{O}}$ Efficiency and effectiveness of tax administration has no significant effect on revenue generation of the state. \\ Correlation}

Where:

RE: Revenue Generation (Dependable Variable)

EandE: Efficiency and Effectiveness of Tax Administration.

Table 4.6.2a Computation of Correlations: Spearman's rhoEandE on RG

\begin{tabular}{|lcc|c|c|}
\hline & & & RG & EandE \\
\hline & \multirow{3}{*}{ RG } & Correlation & 1.000 & .107 \\
& & Coefficient & & .165 \\
Spearman's rho & Sig. (1-tailed) &. & 86 \\
& & $\mathrm{~N}$ & 86 & 1.000 \\
& \multirow{2}{*}{ EandE } & Correlation & .107 &. \\
& & Coefficient & .165 & 86 \\
\hline
\end{tabular}

From the above table, RG has a perfect correlation with RG because every variable has perfect correlation with itself, while RG with EandE are positively correlated with value of 0.107(Weak Relationship). EandE with EandE is also perfectly correlated because every variable has a perfect correlation with itself. This finding is also in line with the researches of Ifere \& Eko (2014), Enahoro \& Olabisi (2012) and Abiola \& James (2012) all who established a positive relationship between efficiency and effectiveness of tax administration with revenue generation.

\section{Regression Analysis}

Table 4.6.2b Coefficientsa

\begin{tabular}{|c|c|c|c|c|c|c|c|c|c|}
\hline \multirow{2}{*}{ Model } & \multicolumn{2}{|c|}{$\begin{array}{c}\text { Unstandardized } \\
\text { Coefficients }\end{array}$} & \multirow{2}{*}{$\begin{array}{c}\begin{array}{c}\text { Standardized } \\
\text { Coefficients }\end{array} \\
\text { Beta }\end{array}$} & \multirow{2}{*}{$\mathrm{t}$} & \multirow{2}{*}{ Sig. } & \multicolumn{2}{|c|}{$\begin{array}{l}95.0 \% \text { Confidence } \\
\text { Interval for B }\end{array}$} & \multicolumn{2}{|c|}{$\begin{array}{l}\text { Collinearity } \\
\text { Statistics }\end{array}$} \\
\hline & B & $\begin{array}{l}\text { Std. } \\
\text { Error }\end{array}$ & & & & $\begin{array}{l}\text { Lower } \\
\text { Bound }\end{array}$ & $\begin{array}{l}\text { Upper } \\
\text { Bound }\end{array}$ & Tolerance & VIF \\
\hline $\begin{array}{c}\text { (Const } \\
\text { ant) }\end{array}$ & 1.376 & .233 & & & & .913 & & & \\
\hline EandE & .110 & .093 & .127 & 1.178 & .242 & -.076 & .296 & 1.000 & $\begin{array}{c}1.00 \\
0\end{array}$ \\
\hline
\end{tabular}




\section{a. Dependent Variable: AverageRG}

From the above regression result, the mean of the regression line (Constant) is 1.376 with a standard error of 0.233 and the variable is statistically significant. It shows that on average, the value of the dependent variable is 1.376 holding the influence of the dependent variable(s) constant.

A unit increase in EandE will increase the dependent variable (RG) by $11 \%$. This shows that EandE with the dependent variable $(\mathrm{RG})$ have positive relationship and EandE is statistically significant.

Table 4.6.2c Model Summary ${ }^{\mathrm{b}}$

\begin{tabular}{|c|c|c|c|c|c|c|c|c|c|}
\hline \multirow{2}{*}{$\begin{array}{l}\text { Mod } \\
\text { el }\end{array}$} & \multirow[b]{2}{*}{$\mathrm{R}$} & \multirow{2}{*}{$\begin{array}{c}\mathrm{R} \\
\text { Square }\end{array}$} & \multirow{2}{*}{$\begin{array}{c}\text { Adjusted R } \\
\text { Square }\end{array}$} & \multirow{2}{*}{$\begin{array}{l}\text { Std. Error of } \\
\text { the Estimate }\end{array}$} & \multicolumn{5}{|c|}{ Change Statistics } \\
\hline & & & & & $\begin{array}{l}\text { R Square } \\
\text { Change }\end{array}$ & $\begin{array}{c}\mathrm{F} \\
\text { Change }\end{array}$ & df1 & df 2 & $\begin{array}{c}\text { Sig. F } \\
\text { Change }\end{array}$ \\
\hline
\end{tabular}

a. Predictors: (Constant), EandE

b. Dependent Variable: RG

From the above table, it can be seen that the value overall fitness of the model which is the R square is $16 \%$ which is the power of the model to explain the dependent variable (RG). The F change revealed1.388.

\section{Discussion}

From the results of the correlation and regression of the study hypothesis, we therefore reject null hypothesis $\left(\mathrm{H}_{0}\right)$ and accept the alternative hypothesis $\left(\mathrm{H}_{1}\right)$ that Efficiency and effectiveness of tax administration has significant effect on revenue generation of the state since, the mean of the regression line (Constant) is 1.376 with a standard error of 0.233 and the variable is statistically significant. It shows that on average, the value of the dependent variable is 1.376 holding the influence of the dependent variable(s) constant.

\subsection{Test of Hypothesis 2: $\mathrm{H}_{O}$ There is no significant relationship between tax payers' enlightenment on payment of tax and revenue generation.}

\section{Correlation}

Where:

RE: Revenue Generation (Dependable Variable)

TPE: Tax Payers' Enlightenment.

Table 4.6.3a Computation of Correlations: Spearman's rho TPE on RG

\begin{tabular}{|c|c|c|c|c|}
\hline & & & RG & TPE \\
\hline Spearman's rho & RG & $\begin{array}{l}\text { Correlation Coefficient } \\
\text { Sig. (1-tailed) } \\
\text { N } \\
\text { Correlation Coefficient } \\
\text { Sig. (1-tailed) } \\
\text { N }\end{array}$ & $\begin{array}{c}1.000 \\
. \\
86 \\
.014 \\
.448 \\
86\end{array}$ & $\begin{array}{c}.014 \\
.448 \\
86 \\
1.000 \\
. \\
86\end{array}$ \\
\hline
\end{tabular}

Regression Analysis

Table 4.6.3b Coefficients ${ }^{\mathrm{a}}$

\begin{tabular}{|c|c|c|c|c|c|c|c|c|c|}
\hline \multirow{2}{*}{ Model } & \multicolumn{2}{|c|}{$\begin{array}{l}\text { Unstandardized } \\
\text { Coefficients }\end{array}$} & \multirow{2}{*}{\begin{tabular}{|c}
$\begin{array}{c}\text { Standardi } \\
\text { zed } \\
\text { Coefficie } \\
\text { nts }\end{array}$ \\
Beta
\end{tabular}} & \multirow{2}{*}{$\mathrm{t}$} & \multirow{2}{*}{ Sig. } & \multicolumn{2}{|c|}{$\begin{array}{l}95.0 \% \text { Confidence } \\
\text { Interval for B }\end{array}$} & \multicolumn{2}{|c|}{$\begin{array}{l}\text { Collinearity } \\
\text { Statistics }\end{array}$} \\
\hline & B & $\begin{array}{l}\text { Std. } \\
\text { Error }\end{array}$ & & & & $\begin{array}{l}\text { Lower } \\
\text { Bound } \\
\end{array}$ & $\begin{array}{l}\text { Upper } \\
\text { Bound }\end{array}$ & $\begin{array}{c}\text { Toleran } \\
\text { ce }\end{array}$ & VIF \\
\hline \multirow{2}{*}{$\begin{array}{c}\text { (Constant) } \\
1 \quad \text { Average } \\
\text { TPE }\end{array}$} & 1.691 & .133 & & $\begin{array}{c}12.68 \\
2\end{array}$ & .000 & 1.426 & 1.956 & & \\
\hline & .031 & .086 & .039 & .357 & .722 & .202 & .141 & 1.000 & $\begin{array}{c}1.00 \\
0\end{array}$ \\
\hline
\end{tabular}

a. Dependent Variable: AverageRG 
From the above table, RG has a perfect correlation with RG because every variable has perfect correlation with itself, while RG with TPE are positively correlated with value of 0.014(Weak Relationship). TPE with TPE is also perfectly correlated because every variable has a perfect correlation with itself. TPE and RG have a positive significant relationship of 0.448 which is a strong relationship. The result above is also in line with the research by Adebisi, (2015) who also establish that a direct positive relationship exists between enlightenment of tax payers on tax payment and revenue generation.

The above regression result for hypothesis two (2) shows that the mean of the regression line (Constant) is 1.691 with a standard error of 0.133 and the variable is statistically significant. It further shows that on average, the value of the dependent variable is 1.691 holding the influence of the dependent variable(s) constant.

A unit increase in TPE will increase the dependent variable (RG) by $31 \%$. This shows that TPE with the dependent variable $(\mathrm{RG})$ have positive relationship and TPE is statistically significant.

\begin{tabular}{|c|c|c|c|c|c|c|c|c|c|c|}
\hline & & & & Tal & $.3 \mathrm{c}$ & el Summ & & & & \\
\hline \multirow{2}{*}{$\begin{array}{l}\text { Mo } \\
\text { del }\end{array}$} & \multirow[b]{2}{*}{$\mathrm{R}$} & \multirow{2}{*}{$\begin{array}{c}\mathrm{R} \\
\text { Square }\end{array}$} & \multirow{2}{*}{$\begin{array}{c}\text { Adjuste } \\
\text { d R } \\
\text { Square }\end{array}$} & \multirow{2}{*}{$\begin{array}{l}\text { Std. Error } \\
\text { of the } \\
\text { Estimate }\end{array}$} & \multicolumn{5}{|c|}{ Change Statistics } & \multirow[b]{2}{*}{$\begin{array}{l}\text { Durbin- } \\
\text { Watson }\end{array}$} \\
\hline & & & & & $\begin{array}{l}\text { R Square } \\
\text { Change }\end{array}$ & $\begin{array}{c}\mathrm{F} \\
\text { Change }\end{array}$ & df1 & df2 & $\begin{array}{c}\text { Sig. F } \\
\text { Change }\end{array}$ & \\
\hline 1 & $.039^{\mathrm{a}}$ & .002 & .010 & .37166 & .002 & .127 & 1 & 84 & .722 & 1.333 \\
\hline
\end{tabular}

a. Predictors: (Constant), AverageTPE

b. Dependent Variable: AverageRG

From the above table, it can be seen that the value overall fitness of the model which is the R square is $39 \%$ which is the power of the model to explain the dependent variable (RG). The F value showed 72.2\%.

Discussion

From the results of the correlation and regression of hypothesis, we therefore reject null hypothesis (Ho2: There is no significant relationship between tax payers' enlightenment on payment of tax and revenue generation) and accept the alternative hypothesis $\left(\mathrm{H}_{1}\right)$ that there is significant relationship between tax payers' enlightenment on payment of tax and revenue generation since the mean of the regression line (Constant) is 1.691 with a standard error of 0.133 and the variable is statistically significant. It further shows that on average, the value of the dependent variable is 1.691 holding the influence of the dependent variable(s) constant.

\subsection{Test of Hypothesis 3: $\mathrm{H}_{O}$ Tax evasion and tax avoidance have no significant effect on revenue generation.}

\section{Correlation}

Where:

RE: Revenue Generation (Dependable Variable)

TEandA: Tax Evasion and Avoidance.

Table 4.6.4a Computation of Correlations: Pearson TEandA on RG

\begin{tabular}{|cc|c|c|}
\hline & & RG & TEandA \\
\hline \multirow{2}{*}{ RG } & Pearson Correlation & 1 & $.437^{* *}$ \\
& Sig. (1-tailed) & & .000 \\
& $\mathrm{~N}$ & 86 & 86 \\
& Pearson Correlation & $.437^{* *}$ & 1 \\
TEandA & Sig. (1-tailed) & .000 & \\
& $\mathrm{~N}$ & 86 & 86 \\
\hline
\end{tabular}

**. Correlation is significant at the 0.01 level (1-tailed).

From the above table, RG has a perfect correlation with RG because every variable has perfect correlation with itself, while RG with TEand A are positively correlated with value of 0.437 (Weak Relationship).

TEand A with TEandA is also perfectly correlated because every variable has a perfect correlation with itself.

The result above is also in line with researches carried out by Adebisi, (2015), Fatoki, (2014) and Modugu, (2014) that there exist a direct and positive relationship between tax avoidance, tax evasion, and personal revenue generation. The practice of tax evasion and tax avoidance reduces the revenue generated but if these practices are curtailed, the revenue to be generated would also increase. 


\begin{tabular}{|c|c|c|c|c|c|c|c|c|c|}
\hline Model & \multicolumn{2}{|c|}{$\begin{array}{l}\text { Unstandardized } \\
\text { Coefficients }\end{array}$} & \begin{tabular}{|c|}
$\mid \begin{array}{c}\text { Standardiz } \\
\text { ed } \\
\text { Coefficien } \\
\text { ts }\end{array}$ \\
Beta
\end{tabular} & $\mathrm{t}$ & Sig. & \multicolumn{2}{|c|}{$\begin{array}{l}95.0 \% \text { Confidence } \\
\text { Interval for B }\end{array}$} & \multicolumn{2}{|c|}{$\begin{array}{l}\text { Collinearity } \\
\text { Statistics }\end{array}$} \\
\hline (Constant) & 1.108 & .126 & & 8.790 & .000 & .858 & 1.359 & & \\
\hline
\end{tabular}

a. Dependent Variable: RG

From the above regression result, the mean of the regression line (Constant) is 1.108 with a standard error of 0.126 and the variable is statistically significant. It shows that on average, the value of the dependent variable is 1.108 holding the influence of the dependent variable(s) constant.

A unit increase in TEandA will increase the dependent variable (RG) by $30.8 \%$. It shows that TE and A with the dependent variable (RG) have positive relationship and TEandA is statistically significant.

Table 4.6.2c Model Summary ${ }^{\mathrm{b}}$

\begin{tabular}{|c|c|c|c|c|c|c|c|c|c|}
\hline \multirow{2}{*}{$\begin{array}{l}\text { Mo } \\
\text { del }\end{array}$} & \multirow[b]{2}{*}{$\mathrm{R}$} & \multirow{2}{*}{$\begin{array}{c}\mathrm{R} \\
\text { Square }\end{array}$} & \multirow{2}{*}{$\begin{array}{c}\text { Adjusted R } \\
\text { Square }\end{array}$} & \multirow{2}{*}{$\begin{array}{l}\text { Std. Error } \\
\text { of the } \\
\text { Estimate }\end{array}$} & \multicolumn{5}{|c|}{ Change Statistics } \\
\hline & & & & & $\begin{array}{l}\text { R Square } \\
\text { Change }\end{array}$ & $\begin{array}{c}\mathrm{F} \\
\text { Change }\end{array}$ & df1 & df 2 & $\begin{array}{c}\text { Sig. F } \\
\text { Change }\end{array}$ \\
\hline 1 & $.437^{\mathrm{a}}$ & .191 & .181 & .33459 & .191 & 19.797 & 1 & 84 & .000 \\
\hline
\end{tabular}

a. Predictors: (Constant), TEandA

b. Dependent Variable: RG

From the above table, it can be seen that the value overall fitness of the model which is the $\mathrm{R}$ is $43.7 \%$ which is the power of the model to explain the dependent variable (RG).

\section{Discussion}

From the results of the correlation and regression of hypothesis, we therefore reject the null hypothesis $\left(\mathrm{H}_{0}\right.$ :Tax evasion and tax avoidance have no significant effect on revenue generation. $)$ and accept the alternative hypothesis $\left(\mathrm{H}_{1}\right)$ that there is significant relationship between Tax evasion and tax avoidance have no significant effect on revenue generation. Tax evasion and avoidance with revenue generation of the state are dependent with each other. Since the mean of the regression line (Constant) is 1.108 with a standard error of 0.126 and the variable is statistically significant. It shows that on average, the value of the dependent variable is 1.108 holding the influence of the dependent variable(s) constant. This shows that dependency exist between the both variables.

\subsection{Conclusion and Summary}

The study set out to examine the effect of tax administration on revenue generation in Gombe state. The major source of data for this study is the primary data that was collected through the use of questionnaires administered to the state board of internal revenue. The research designed adopted was the survey research design and the sampling technique adopted was simple random sampling technique. Cronbach's Alpha diagnose was carried out to seek for reliability of the questions contained in the questionnaire. Three hypotheses were presented and tested in this research by use of Spearman's Rank correlation, Pearson correlation and linear regression.

The correlation results of the first model of study revealed that there is a positive correlation with value of 0.107 between efficiency and effectiveness of tax administration with revenue generation. The second model also showed that there is a perfect correlation between tax payers' enlightenment and revenue generation. The variables are positively correlated with a value of 0.014 . From the correlation result of the third variable, there exist a perfect relationship between the variables tax evasion and avoidance with revenue generation and it revealed a positive correlation with value of 0.437 .

From the regression results, efficiency and effectiveness of tax administration was found to have a significant positive effect on Revenue generation at 0.05 (significance) level of confidence. The $R 2$ showed that the model explained $16 \%$ of variance in revenue generation and it was found to be fit as the F-statistic was also significant at both $5 \%$ level of significance. 
From the regression results of the second model, tax payers enlightenment was found to have holding influence on the dependent variable which is revenue generation with constant of 1.691 and it was found to be fit as the F-statistic was also significant at $5 \%$ level of significance.

Result from the third model revealed that Tax evasion and avoidance have significant positive impact on Revenue generation at 0.05 (significance) levels of confidence. The $R$ showed that the model explained $43.7 \%$ of variance on revenue generation and it was found to be fit as the F-statistic was also significant at $5 \%$.

This study is undertaken primarily to determine effect of tax administration on revenue generation using the Gombe State Board of Internal Revenue as the case study. Despite the identification of taxation as one of the most reliable sources from which any government could derive the necessary revenue for her various development functions, Gombe State has been performing low in terms of tax yield. This is due majorly to several problems beclouding the system of tax administration in the state. Some of the major problem responsible for this trend include: improper tax assessment (high tax rate), tax evasion and avoidance, lack of awareness on part of citizens. The result shows a clear deficit in infrastructural development and provision of social services which are supposed to be provided from tax revenue.

\subsection{Recommendations}

To reverse this trend, firstly, the government needs to formulate a sound regulatory framework to ensure efficiency and effectiveness in the administration of taxes is imperative. There is need for government to ensure that tax policies are reviewed and updated regularly. This has the effect of bringing innovation in tax administration and effective revenue generation. Government should strive to ensure that tax rates are kept moderate in order to avoid tax evasion/avoidance. There should be an efficient information system which will enable tax authorities networking to encamp tax payer that avoids or evades tax. This will help significantly in limiting the incidence of tax evasion.

Secondly, the tax administration in the state should be granted total autonomy. This will make the internal revenue board to recruit the best professionals to manage the professional posts in the state. In this regard, it will be possible for the authorities to attract the best brains and pay them handsomely. It is my feeling that tax officials being at the vanguard of generating revenue and increasing the wealth of the nation should be given full autonomy in tax administration.

Thirdly, better mechanisms for assessments and collection of tax should be put in place to enable the tax authority function effectively, as the board lack basic facilities and necessary working material there by reducing their work efficiency and professionalism. I recommend that the government should assist in Provision of the required tools, facilities and environment necessary for tax administration to increase the rate of revenue generated.

Furthermore, there is an urgent need for the state governments to clearly state the basic objectives of its tax system and the relationship between these objectives. This will assist to give the tax administrators a sense of direction and make the tax payer see clearly the reasons he/she should pay his/her tax as at when due.

Also, the tax system should be fully modernize and automated, improve tax payer convenience in the assessment and payment process whilst at the same time entrenching effective and modern human resource management practices in the tax authorities. The board should be provided with adequate data processing system, the power generating sets working, then it will be possible for the revenue authority to have complete data about tax payers with a view to generating a data bank with which a proper monitoring of taxes paid, or and to be paid by tax payers can be done.

Again, there should be enlightenment campaign to Motivate people to pay their taxes promptly as they are used for community development projects. It has been the fault of government by believing that tax education is not necessary and hence no investments into tax matters. Most people have these natural dislike for tax, if proper tax education is conducted, the tax payer will appreciate the importance of tax and not just its dark side.

Finally, there should be judicious use of tax payers' money should be made and be seen to have been properly utilized. This will encourage tax payers to continue to pay taxes.

\section{References}

[1]. Abata, M. (2014). The Impact of Tax Revenue on Nigerian Economy (Case of Federal Board of Inland Revenue). Journal of Policy and Development Studies. 
[2]. Abiola , J., \& Asiweh, M. (2012). Impact of Tax Administration on Government Revenue in a Developing Economy- A Case Study of Nigeria. International Journal of Business and Social Science.

[3]. Adebisi, J. F., \& Gbegi, D. O. (2013). Effect of Tax Avoidance and Tax Evasion on Personal Income Tax Administration in Nigeria. American Journal of Humanities and Social Sciences.

[4]. Adedokun, A. J., \& Oyesiji, Y. K. (2015). Revisiting Taxation and advancing criteria for a good tax system in Nigeria. Global Advance Research of Economics, Accounting and Finance.

[5]. Afuberoh, D., \& Okoye, E. (2014). The Impact of Taxation on Revenue Generation in Nigeria: A Study of Federal Capital Territory and Selected States. International Journal of Public Administration and Management Research.

[6]. Angahar, P. A., \& Alfred, S. I. (2012). Personal Income Tax Administration in Nigeria: Challenges and Prospects for increased revenue generation from self employed persons in the society. Global Business and Economics Research Journal.

[7]. Ayodele, O. (2006). Tax Policy Reform in Nigeria. World Institue for Developmental Economic Research.

[8]. Chandia, K. E., Sabir, R. I., Zulfiqar, S., Sarwer, B., \& Bahadur, W. (2014). Determinants of Revenue Generation Capacity in the Economy of Pakistan. Journal of Basic and Applied Science Research.

[9]. Chatama, J. (2013). The Impact of ICT on Taxation: the case of Large Taxpayers Department of Tanzania Revenue Authority. Developing Country Studies.

[10]. Collins, J., \& Hussey, R. (2003). Business Research: A practical guide for undergradute and post graduate students. New York: Palgrave Macmillan.

[11]. Darono. (2015). Service onnovation in the complex environment of tax administration: the Indonesian Public sector perspective. International Journal of Innovation and Regional Development.

[12]. Efunboade, A. O. (2014). Impact of ICT on Tax Administration in Nigeria. Computer Engineering and Intelligent System.

[13]. Enahoro, J. A., \& Olabisi, J. (2012). Tax Administration and Revenue Generation of Lagos State Government, Nigeria. Research Journal of Finance and Accounting.

[14]. Fatoki, J. O. (2014). AN Emperical Study of Tax Evasion and Tax Aviodance: A Critical Issue in Nigeria Economic Development. Journal of Economics and Suitanable Development.

[15]. Gurama, Z., \& Mansor, M. (2015). Tax Administration Problems and Prospect: A Case of Gombe State. International Journal of Arts and Commerce.

[16]. Hassan, G. D. (2012). Tax Administration in Kano State: Problems and Prospects. International Journal of Arts and Commerce.

[17]. Ifere , E. O., \& Eko, O. (2014). Tax Innovation, Administration and Revenue Generation in Nigeria: Case of Cross River State. Internation Journal of Science, Behavioral, Educational, Economics and Industrial Engineering.

[18]. Isaac, L. (2015). An Assessment of the Contributions of Tax Revenue to Economic Development in Nigeria. International Journal of Business, Management and Allied Sciences.

[19]. Kwame, J. A., Tchao, B. T., \& Poku, K. (2013). Integration of Tax Administration to Curb Import and Domestic Tax Evasions in Ghana. International Journal of Business and Social Research.

[20]. Madugba, J. U., Ekwe, M. C., \& Kalu, J. M. (2015). Corporate Tax and Revenue Generation: Evidence from Nigeria. Journal of Emerging Trends in Economics and Management Sciences.

[21]. Mehrara, M. (2016). Journal of Word Science. The relationship between tax income, government revenue.

[22]. Nawaz, F. (2010). Exploring the Relationships between Corruption and Tax Revenue. Global Journal of Management and Business Research.

[23]. Okoye , P. V., \& Ezejiofor, R. (2014). Impact of E-Taxation on Revenue Generation in Enugu, Nigeria. International Journal of Advance Research.

[24]. Pallant, J. (2011). SPSS srtwival munual: A step by step grtide to data analysis using SPSS for windows Eng1and: McGraw Hill open University Press.

[25]. Sekaran, U., \& Bougie, R. (2010). Research Methods for Business: A skill building appraoch (5 ed.). Chichestea: John Willey and SOns Ltd.

[26]. Wausi, M. L. (2015). Effects of transfer pricing on revenue generation by Multinational enterprises in Kenya. Global Journal of Management and Business Research. 